\title{
Variation in Growth Rate and Colony Morphology of Phytophthora parasitica Induced by Metalaxyl*
}

\author{
Tun-tschu CHANG**, ${ }^{*}$ and Wen-hsiung $\mathrm{KO}^{* *}$
}

\begin{abstract}
Growing isolates P991 and P731 of Phytophthora parasitica on medium containing 25 $\mu \mathrm{g} / \mathrm{ml}$ metalaxyl for 6 weeks, caused $66-74 \%$ of their single-zoospore cultures to increase the range of growth rates on metalaxyl-free medium. Metalaxyl treatment also caused each isolate to produce six colony types, including the parental type, on medium without metalaxyl. Growth rate and colony morphology of six single-zoospore cultures each representing a different colony type did not change after five successive subcultures. However, all the five colony-type variants produced single-zoospore cultures with greater variation in growth rate than did the parental type.
\end{abstract}

(Received July 8, 1991)

Key words : variation, growth rate, colony morphology, Phytophthora parasitica, metalaxyl.

\section{INTRODUCTION}

Inhibitory effects of fungicides on fungal pathogens are transitory. After transfer to a fungicidefree medium, treated organisms often resume growth and produce normal colonies. Metalaxyl (N-[2, 6-dimethylphenyl]-N-[methoxyacetyl] alanine methyl ester) is a systemic fungicide widely used for controlling oomycete plant pathogens ${ }^{10)}$. During our recent study on the effect of metalaxyl on mating type of Phytophthoras), we noticed that some of the single-zoospore cultures obtained from Phytophthora parasitica Dastur (Phytophthora nicotianae Breda de Haan) pre-incubated for 6 weeks on medium containing metalaxyl showed abnormal growth on metalaxyl-free medium. We, therefore, investigated the effect of metalaxyl on growth rate and colony morphology of $P$. parasitica.

\section{MATERIALS AND METHODS}

Metalaxyl treatment. Isolates P991 (A1) and P731 (A2) of P. parasitica obtained from Dr.G.A. Zentmyer, University of California, Riverside, were grown on V-8 agar $\left(10 \% \mathrm{~V}-8\right.$ juice, $0.02 \% \mathrm{CaCO}_{3}$ and $2 \%$ agar) for four days. Four culture blocks $(10 \times 10 \times 3 \mathrm{~mm})$ from the colony margin of each isolate were placed on separate $90-\mathrm{mm}$ petri dishes containing V-8 agar supplemented with $25 \mu \mathrm{m}$ a.i. $/ \mathrm{ml}$ metalaxyl (Subdue 2E; Ciba-Geigy Corp., Greensboro, NC). Metalaxyl was added aseptically to the medium at about $60^{\circ} \mathrm{C}$ with a Pipetman digital microliter pipet (Rainin Instrument Co., Emeryville, CA) after autoclaving. Because the commercial formulation of metalaxyl consists mainly of metalaxyl dissolved in xylene, the medium remained sterile after addition of metalaxyl. Additional treatments consisted of V-8 agar supplemented with $75 \mu \mathrm{g} / \mathrm{ml}$ xylene (the concentration in the medium amended

${ }^{*}$ Journal Series No. 3603 of the Hawaii Institute of Tropical Agriculture and Human Resources. Supported in part by the U.S. Department of Agriculture under CSRS special Grand No. 85-CRSR-2-2661, managed by the Pacific Basin Advisory Group (PBAG).

** Department of Plant Pathology, Beaumont Agriculture Research Center, University of Hawaii, Hilo, Hawaii 96720, U.S.A.

+ Present address: Taiwan Forestry Research Institute, 53 Nan Hai Road, Taipei, Taiwan 
with metalaxyl) and V-8 agar alone. Three dishes for each treatment were sealed with Parafilm and kept in the same plastic container $(40 \times 25 \times 15 \mathrm{~cm})$ at $24^{\circ} \mathrm{C}$.

Isolation of single zoospores. Both isolates P991 and P731 grew to about $20 \mathrm{~mm}$ in diameter after 4 weeks on V-8 agar supplemented with metalaxyl but reached the edge of the dishes containing V-8 agar alone or V-8 agar supplemented with xylene. Six mycelial blocks $(10 \times 5 \times 3 \mathrm{~mm})$ were cut from the margin of colonies on metalaxyl medium and from the edge of colonies on xylenesupplemented or control dish and placed in $10 \mathrm{ml}$ sterile distilled water in separate $60-\mathrm{mm}$ petri dish. After incubation at $24^{\circ} \mathrm{C}$ under continuous cool white fluorescent light (2,000 lux) for 2 days to induce sporangial production, zoospores were released from the sporangia by chilling the cultures at $5^{\circ} \mathrm{C}$ for 15 $\min ^{6}$. Approximately 100 zoospores from each treatment, as determined by the microliter pipet method $^{7)}$ were spread on $2 \%$ water agar in separate petri dish. After incubation at $24^{\circ} \mathrm{C}$ for 2 days, those colonies originated from single zoospores were transferred to $5 \% \mathrm{~V}-8$ agar (5\% V-8 juice, $0.02 \%$ $\mathrm{CaCO}_{3}$ and $2 \%$ Bacto agar). Five colonies were distributed equidistant around the edge of each dish, and developing cultures were transferred and used in the study before the colonies merged. A total of 300 single-zoospore cultures (100 each from the fungus growing on medium with metalaxyl, medium with xylene, and medium alone) was obtained from each of isolates P991 and P731.

Growth rate and colony morphology. Four mycelial discs $(4 \mathrm{~mm})$ were cut from the advancing margin of each single-zoospore culture and placed equidistant around the perimeter of a petri dish containing $10 \% \mathrm{~V}-8$ agar. After incubation at $24^{\circ} \mathrm{C}$ for 4 days, colony morphology and linear growth were recorded. Two replicate dishes were used for each single-zoospore culture, and the experiment was repeated.

\section{RESULTS}

On the metalaxyl medium isolates P991 and P731 of P. parasitica were strongly inhibited. Growth first was visible after 7 days, reaching approximately $20 \mathrm{~mm}$ in diameter after 4 weeks. Between week 4 and 6 , growth of either isolate was not detectable. Medium containing xylene was not inhibitory to

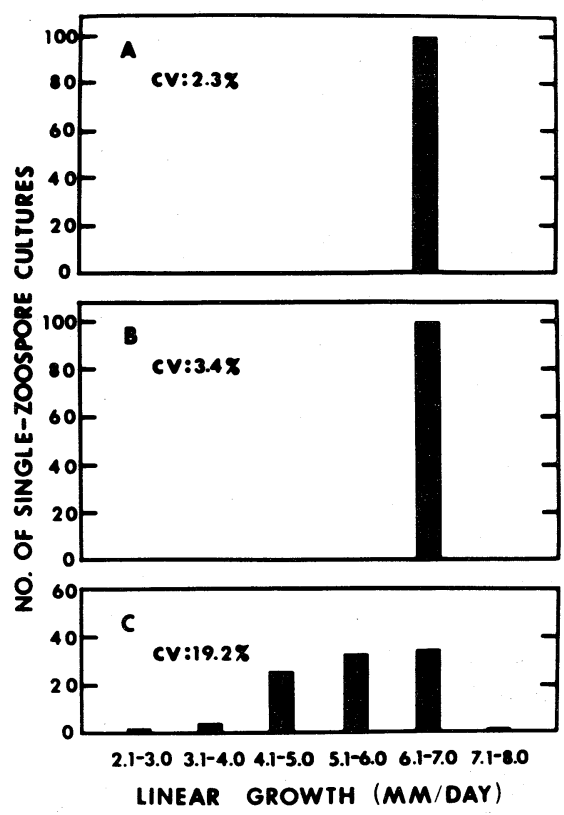

Fig. 1. Growth-rate distributions of single-zoospore cultures obtained from isolate P991 of Phytophthora parasitica grown for 6 weeks on V-8 agar alone (A), V-8 agar containing xylene (B) and V-8 agar containing metalaxyl at $25 \mu \mathrm{g} / \mathrm{ml}(\mathrm{C})$. CV: coefficient of variation. 


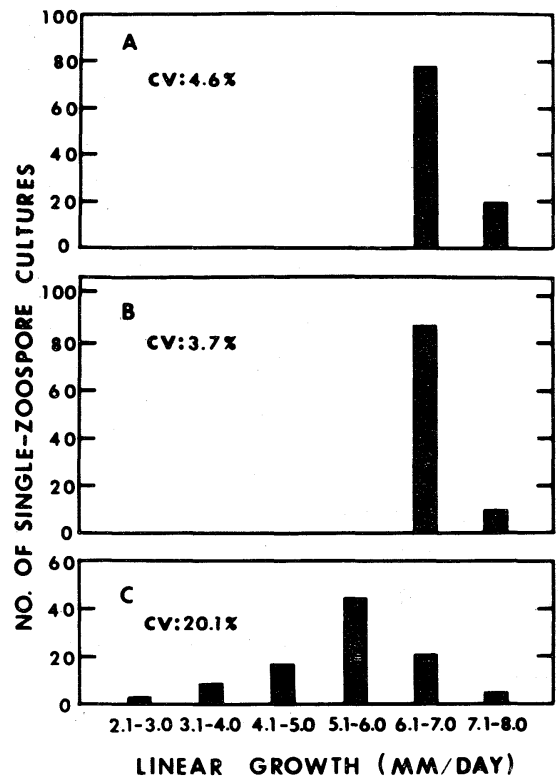

Fig. 2. Growth-rate distributions of single-zoospore cultures obtained from isolate P731 of Phytophthora parasitica grown for 6 weeks on V-8 agar alone (A), V-8 agar containing xylene (B) and V-8 agar containing metalaxyl at $25 \mu \mathrm{g} / \mathrm{ml}(\mathrm{C})$. CV: coefficient of variation.

Table 1. Colony types in single-zoospore cultures of Phytophthora parasitica obtained from isolates grown at $24^{\circ} \mathrm{C}$ for 6 weeks on V-8 agar alone, V-8 agar supplemented with $75 \mu \mathrm{g} / \mathrm{ml}$ xylene and V-8 agar supplemented with $25 \mu \mathrm{g} / \mathrm{ml}$ metalaxyl

\begin{tabular}{|c|c|c|c|c|c|c|c|}
\hline \multirow{2}{*}{$\begin{array}{l}\text { Isolate and } \\
\text { treatment }\end{array}$} & \multicolumn{7}{|c|}{ Colony type ${ }^{\text {a) }}$ and no. of cultures } \\
\hline & $\mathrm{A}$ & $\mathrm{B}$ & $\mathrm{C}$ & $\mathrm{D}$ & $\mathrm{E}$ & $\mathrm{F}$ & Total \\
\hline \multicolumn{8}{|l|}{ P991 } \\
\hline Metalaxyl & 43 & 17 & 2 & 35 & 2 & 1 & 100 \\
\hline Xylene & 100 & 0 & 0 & 0 & 0 & 0 & 100 \\
\hline None & 100 & 0 & 0 & 0 & 0 & 0 & 100 \\
\hline \multicolumn{8}{|l|}{ P731 } \\
\hline Metalaxyl & 54 & 32 & 2 & 7 & 4 & 1 & 100 \\
\hline Xylene & 100 & 0 & 0 & 0 & 0 & 0 & 100 \\
\hline None & 100 & 0 & 0 & 0 & 0 & 0 & 100 \\
\hline
\end{tabular}

a) Single-zoospore cultures grown on V-8 agar at $24^{\circ} \mathrm{C}$ for 5 days. Symbols: A, typical, irregular zonal pattern, abundant aerial grwoth; B, uniform texture, abundant aerial growth; C, uniform fine texture, moderate aerial growth, usually slow or intermediate in growth; D, zonal pattern, little aerial growth, radiate; E, irregular mosaic pattern, moderate aerial growth, non-radiate, usually intermediate in growth; $\mathrm{F}$, irregular pattern, little aerial growth, radiate, usually slow or intermediate in growth.

either isolate. Colonies of both isolates on medium containing xylene and unsupplemented reached the edge of culture dishes within 4 days.

Growth rates of single-zoospore cultures obtained from isolates P991 and P731 over 6-week period on xylene-supplemented medium and unsupplemented were very uniform. The range of growth rates of single-zoospore cultures from the fungus growing on xylene-supplemented medium was $6.3-7.0 \mathrm{~mm} /$ day for isolate P991 and 6.3-7.9 mm/day for isolate P731, while that from the fungus growing on medium alone was $6.1-6.8 \mathrm{~mm} /$ day for isolate P991 and 6.1-7.7 mm/day isolate P731 (Figs. 1 and 2). However, exposure of these isolates to metalaxyl for 6 weeks greatly increased the ranges of growth rates among their single-zoospore cultures on medium without metalaxyl; 2.3-7.3 mm/day for P991 (Fig. 1) and 2.6$7.1 \mathrm{~mm} /$ day for P731 (Fig. 2). Metalaxyl treatment induced change in growth rate in 66 and $74 \%$ of single-zoospore cultures of isolates P991 and P731, respectively. 


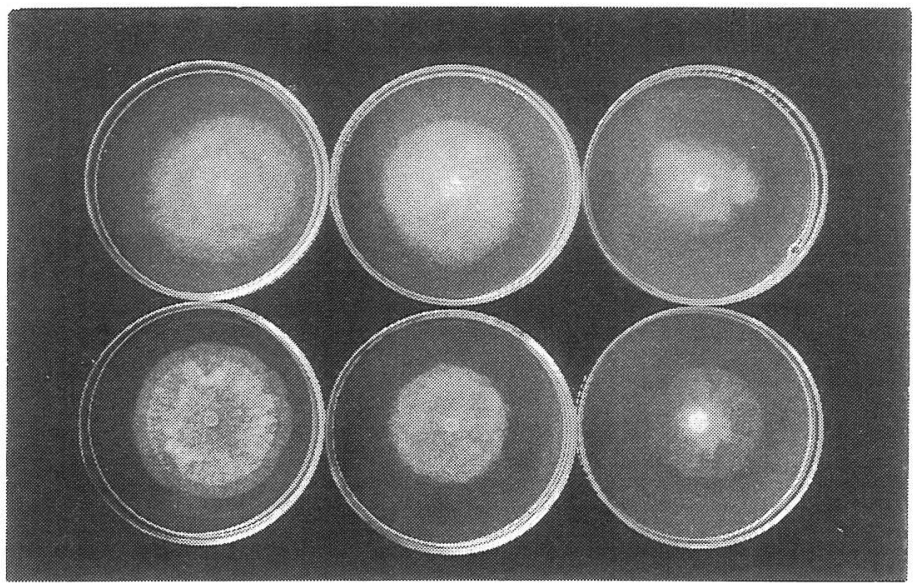

Fig. 3. Colony patterns displayed by single-zoospore cultures obtained from Phytophthora parasitica treated with metalaxyl. Cultures were grown on V-8 agar at $24^{\circ} \mathrm{C}$ for 5 days. Upper left, type A (parental type); upper center, type B; upper right, type C; lower left, type D; lower center, type E; lower right, type F. Isolates P991 and P731 displayed the same types.

Table 2. Variation in growth rates among single-zoospore cultures from isolates each representing one of the six colony types from isolate P991 of Phytophthora parasitica grown for 6 weeks on $\mathrm{V}-8$ agar containing $25 \mu \mathrm{g} / \mathrm{ml}$ metalaxyl

\begin{tabular}{|c|c|c|c|c|c|}
\hline \multirow[b]{2}{*}{ Isolate } & \multirow[b]{2}{*}{$\begin{array}{l}\text { Colony } \\
\text { type }\end{array}$} & \multirow{2}{*}{$\begin{array}{l}\text { Original } \\
\text { growth } \\
\text { rate } \\
(\mathrm{mm} / \text { day })\end{array}$} & \multicolumn{3}{|c|}{ Single-zoospore cultures } \\
\hline & & & $\begin{array}{l}\text { Range of } \\
\text { growth rate } \\
\text { (mm/day) }\end{array}$ & $\mathrm{CV}(\%)^{\mathrm{b})}$ & $\begin{array}{c}\text { Total } \\
\text { no. }\end{array}$ \\
\hline P991-1 ${ }^{\text {a) }}$ & A & 6.1 & $5.1-6.4$ & 4.8 & 64 \\
\hline P991-2M & A & 5.6 & $5.3-6.4$ & 4.7 & 60 \\
\hline P991-14M & $\mathrm{B}$ & 6.3 & $3.0-6.6$ & 18.1 & 75 \\
\hline P991-1M & $\mathrm{C}$ & 2.5 & $0.4-3.8$ & 40.0 & 60 \\
\hline P991-23M & $\mathrm{D}$ & 5.0 & $1.3-5.9$ & 53.3 & 72 \\
\hline P991-12M & $\mathrm{E}$ & 5.6 & $4.0-6.8$ & 7.5 & 60 \\
\hline P991-19M & $\mathrm{F}$ & 4.9 & $1.0-6.1$ & 43.6 & 60 \\
\hline
\end{tabular}

a) Single-zoospore culture from non-treated control.

b) $\mathrm{CV}$, coefficient of variation.

Single-zoospore cultures obtained from isolates P991 and P731 grown on medium with xylene and unsupplemented for 6 weeks were uniform and similar in colony appearance to their respective parents (Table 1). However, after exposure to metalaxyl for 6 weeks, each isolate produced zoospores that gave rise to six colony types, including the parental type A, on medium without metalaxyl (Table 1, Fig. 3). Metalaxyl treatment induced changes in colony appearance in $57 \%$ of single-zoospore cultures of isolate P991. About $65 \%$ of the variants belonged to colony type $\mathrm{D}$, which produced zonal, radiate growth and little aerial growth. The same metalaxyl treatment induced changes in colony appearance in $46 \%$ of single-zoospore cultures of isolate P731. About $70 \%$ of these variants belonged to colony type $\mathrm{B}$, having a uniform texture and abundant aerial growth.

When isolates of zoospore cultures each representing one of the six colony types from P991 were successively subcultured five times, their growth rates were not significantly different from the original rates and none of them changed colony appearance. However, all the five colony-type variants produced single-zoospore cultures with greater variation in growth rate than did the parental type (Table 2). The range of growth rate among single-zoospore cultures from isolate P991-2M was similar to that from the control isolate. All the single-zoospore cultures were similar to their parents in colony 
appearance.

When single-zoospore cultures were obtained from isolates P991 and P731 grown on medium containing $25 \mu \mathrm{g} / \mathrm{ml}$ metalaxyl for 4 weeks, variants were detected only in one of three tests (data not shown). In that positive test, $28 \%$ of the single-zoospore cultures from P991 were morphological variants and $22 \%$ were growth-rate variants. Single-zoospore cultures from isolate P731 produced $12 \%$ morphological variants and $14 \%$ growth-rate variants.

\section{DISCUSSION}

Exposure of $P$. parasitica to metalaxyl for 6 weeks resulted in considerable variation for growth rate and colony appearance among the zoospore progeny. Such effect of metalaxyl is similar to segregation for growth rate and colony morphology resulting from selfing of this fungus ${ }^{2}$. The mechanism for induction of variation by metalaxyl in P. parasitica remains to be investigated. Holt and Paxton $^{5}$ also observed variation in virulence after successive transfers of Phytophthora megasperma f. sp. glycinea on medium amended with metalaxyl.

Consistent changes of colony morphology and growth rate in $P$. parasitica occurred only after exposure to metalaxyl for 6 weeks but not 4 weeks. Whether long-term exposure to other fungicides also can cause similar changes of fungi deserves further investigations.

Fungi usually are inhibited by fungicides only in the presence of these chemicals, and revert to. normal growth and appearance after being transferred to a medium free from these chemicals. Although development of resistance to fungicides by fungi after their exposure to those chemicals is relatively common, reports on changes in other characteristics induced by fungicides are very rare. Durieu-Trautmann and Tavlitz $\mathrm{ki}^{4)}$ reported that chloramphenicol and ethidium-bromide induced stable change of Ustilago cynodontis from hyphal cells to yeast-like colonies. Shaw and Elliot' ${ }^{9)}$ also obtained some stable morphological variants of $P$. cactorum when a wild type was treated with streptomycin. Recently several fungicides including metalaxyl have been found to be capable of inducing mating-type change and subsequently change in hormone production and reception in species of Phytophthora ${ }^{1,3,6,8)}$.

\section{Literature cited}

1. Ann, P.J. and Ko, W.H. (1989). Effect of chloroneb and ethazol on mating type of Pytophthora parasitica and P. cinnamomi. Bot. Bull. Acad. Sinica $30: 207-210$.

2. Ann, P.J. and Ko, W.H. (1990). Growth rate and colony morphology of progenies of zoospores and selfed oospores of Phytophthora parasitica. Mycologia 82 : 693-697.

3. Chang, T.T. and Ko, W.H. (1990). Effect of metalaxyl on mating type of Phytophthora infestans and P. parasitica. Ann. Phytopath. Soc. Japan 56 : 194-198.

4. Durieu-Trautmann, O. and Tavlitzki, J. (1975). Reversible and permanent effects of the carbon and various antibiotics on the morphology and metabolic properties of Ustilago cynodontis cells. J. Cell Biol. 66 : 102113.

5. Holt, J.S. and Paxton, J.D. (1987). Effect of in vitro metalaxyl treatments on virulence of Phytophthora megasperma f. sp. glycinea. Phytopathology 77 : 1703 (Abstr.).

6. Ko, W.H. (1981). Reversible change of mating type in Phytophthora parasitica. J. Gen. Microbiol. 125 : 451454 .

7. Ko, W.H., Chase, L. and Kunimoto, R.K. (1973). A microsyringe method for determining concentration of fungal propagules. Phytopathology $63: 1206-1207$.

8. Ko, W.H., Lee, C.J. and Su, H.J. (1986). Chemical regulation of mating type in Phytophthora parasitica. Mycologia 78 : 134-136.

9. Shaw, D.S. and Elliot, C.G. (1968). Streptomycin resistance and morphological variation in Phytophthora cactorum. J. Gen. Microbiol. 51: 75-84.

10. Ureh, P.A., Schwinn, F.J. and Staub, T. (1977). CGA 48988, a novel fungicide for control of late blight, downy mildew, and related soil-borne diseases. Proc. 9th Brit. Crop Prot. Conf. 2: 623-631. 


\section{和 文 摘 要}

T.T. ChAng and M.H. Ko：メタラキシル剤によって誘導される疫病菌 Phytophthora parasitica の菌系伸長と菌そ う形態の変異

疫病菌 Phytophthora parasitica（P991 および P731 菌株）をメタラキシル剂 $(25 \mu \mathrm{g} / \mathrm{ml}$ ) を含む培地で 6 週間培養 したところ，その単遊走子分離菌株の 66 〜 $74 \%$ がメタラキシルを含まない培養に比べて生長速度の変動幅が増大し た。このメタラキシル処理菌株を普通培地に移植すると, 菌そうの形態, 性状は 6 種（親株型を含む）に類別された。 これら 6 形態株に由来する単遊走子分離菌株は, 引き続く 5 回の移植培養によっても菌系伸長速度および菌そう形態 に変化は認められなかった。ただし, 菌そう形態変異株の方が親株に比べれば伸長速度の変異幅が大きく現れた。 